\title{
Perbedaan efektivitas jus tomat (Lucopersicon esculentum Mill.) dan jus apel (Mallus sylvestris Mill.) sebagai bahan alami pemutih gigi
}

\author{
${ }^{1}$ Enny F. S. Lumuhu \\ ${ }^{2}$ Martha M. Kaseke \\ ${ }^{3}$ Wulan G. Parengkuan
}

\author{
${ }^{1}$ Kandidat Skripsi Program Studi Pendidikan Dokter Gigi Fakultas Kedokteran \\ ${ }^{2}$ Bagian Anatomi-Histologi Fakultas Kedokteran \\ ${ }^{3}$ Program Studi Pendidikan Dokter Gigi \\ Universitas Sam Ratulagi Manado \\ E-mail: ennylumuhu@gmail.com
}

\begin{abstract}
Teeth appearance plays an important role in human interaction. One of its problems is tooth discoloration which can affect personal self confidence and appearance. Chemicals for whitening the teeth can cause negative effects such as decreased enamel hardness and gingival iritaion. An alternative material that can be used for that purpose is natural substance inter alia tomato juice (Lucopersicon esculentum Mill.) which contains hydrogen peroxide and apple juice (Mallus sylvestris Mill.) which contains malic acid. This study aimed to determine the difference in effectiveness of tomato juice and apple juice as natural bleaching agents. This was a true experimental study with a pretest postest only control group design. There were 30 samples of post-extraction anterior teeth soaked in coffee for 12 days and were further divided into 3 groups, each of 10 samples. Group 1 was immersed in tomato juice; group 2 was immersed in apple juice; and group 3 as the positive control was immersed in carbamide peroxide $10 \%$. Each group was observed after 1 day, 3 days, and 5 days. The color change was measured by using CIEL*a*b method. The results showed that tomato juice, apple juice, and carbamide peroxide $10 \%$ could whiten the teeth. However, tomato juice was more effective compared to apple juice and carbamide peroxide $10 \%$. Apple juice and carbamide peroxide $10 \%$ did not show any significant difference in color change.
\end{abstract}

Keywords: tomato juice, apple juice, carbamide peroxide $10 \%$, tooth discoloration

\begin{abstract}
Abstrak: Penampilan gigi berperan dalam interaksi manusia. Masalah dalam penampilan gigi salah satunya ialah perubahan warna gigi yang dapat memengaruhi kepercayaan diri dan keindahan penampilan seseorang. Penggunaan bahan kimia untuk memutihkan gigi dapat berdampak negatif seperti penurunan kekerasan email dan iritasi gingiva. Bahan alternatif yang dapat digunakan untuk memutihkan gigi yaitu dengan bahan alami antara lain jus tomat (Lucopersicon esculentum Mill.) yang mengandung hidrogen peroksida dan jus apel (Mallus sylvestris Mill.) yang mengandung asam malat. Penelitian ini bertujuan untuk mengetahui perbedaan efektivitas jus tomat dan jus apel sebagai bahan alami pemutih gigi. Terdapat 30 sampel gigi anterior pasca ekstraksi yang direndam kopi selama 12 hari. Sampel dibagi menjadi 3 kelompok masing-masing terdiri dari 10 sampel. Kelompok 1 direndam dalam jus tomat; kelompok 2 direndam dalam jus apel; dan kelompok 3 sebagai kontrol positif menggunakan karbamid peroksida 10\%. Setiap kelompok dilakukan pengamatan 1 hari, 3 hari dan 5 hari. Perubahan warna diukur menggunakan metode CIEL*a*b. Hasil penelitian mendapatkan jus tomat, jus apel, dan karbamid peroksida 10\% dapat memutihkan gigi. Jus tomat lebih efektif memutihkan gigi dibandingkan jus apel dan karbamid peroksida 10\%. Jus apel dan karbamid peroksida $10 \%$ tidak memiliki perbedaan memutihkan gigi yang signifikan. Kata kunci: jus tomat, jus apel, karbamid peroksida 10\%, perubahan warna gigi
\end{abstract}


Penampilan gigi merupakan aspek penting yang berperan dalam interaksi sosial manusia. Begitu banyak masalah yang dapat disebabkan oleh gigi yang tidak dirawat dengan baik. Prevalensi penduduk Indonesia yang memiliki masalah gigi dan mulut menurut Riskesdas tahun 2007 dan 2013 meningkat dari 23,2\% menjadi $25,9 \%$. Masalah yang dapat ditemukan ialah karies gigi, keluhan sakit gigi dan mulut, gigi berjejal, gigi goyang, pemakaian gigi tiruan, perubahan warna gigi, dan lainnya. Permasalahan gigi dan mulut masih memiliki kecenderungan untuk meningkat setiap tahunnya; oleh sebab itu perubahan warna gigi juga memiliki kemungkinan untuk terus meningkat setiap tahunnya. Gigi yang mengalami perubahan warna dapat memengaruhi kepercayaan diri dan keindahan penampilan seseorang. ${ }^{1}$

Perubahan warna gigi dapat disebabkan karena faktor ekstrinsik dan intrinsik. Perubahan warna karena faktor ekstrinsik ditemukan pada permukaan luar gigi yang biasa disebabkan oleh noda/stain tembakau, minuman kopi. Perubahan warna karena faktor intrinsik ialah noda yang terdapat di dalam email dan dentin yang biasanya disebabkan oleh tetracycline stain. ${ }^{2}$ Perubahan warna gigi atau diskolorisasi gigi dapat ditanggulangi dengan dua cara yaitu menggunakan bahan kimia dan menggunakan bahan alami. Bahan kimia digunakan oleh dokter gigi ketika melakukan perawatan dental bleaching. Dental bleaching merupakan suatu cara memutihkan kembali gigi yang berubah warna menjadi lebih putih dengan proses perbaikan secara kimiawi. ${ }^{3}$

Penggunaan bahan kimia pada dental bleaching tentunya akan menimbulkan dampak negatif, antara lain dapat menyebabkan penurunan nilai kekerasan permukaan email, iritasi gingiva, gigi sensitive, dan biaya yang tidak murah. ${ }^{4-6}$ Dampak negatif dari penggunaan bahan kimia untuk dental bleaching mendorong penulis untuk meneliti penggunaan bahan alami sebagai pemutih gigi.

Menurut penelitian sebelumnya bahan alami dapat digunakan sebagai alternatif pemutih gigi yang lebih aman dan terjangkau. Bahan alami yang dapat dimanfaatkan ialah anggur (Vitis Vinifera L.), stroberi (Fragaria xannanassea,) tomat (Lucopersicon esculentum Mill.) dan apel (Mallus sylvestris Mill). ${ }^{7-10}$

Tomat tentunya bukan hal yang asing lagi dan manfaat tomat bagi kehidupan sehari-hari tidak dapat diragukan lagi, sebagian besar masyarakat Indonesia menggunakan tomat sebagai penambah bumbu masakan, minuman, bahan industri, bahkan biasa digunakan untuk kecantikan wajah. Hasil penelitian sebelumnya melaporkana bahwa kandungan hidrogen peroksida dan peroksidase pada tomat dapat digunakan sebagai bahan alternatif untuk memutihkan gigi. ${ }^{7}$

Apel juga merupakan buah yang banyak digemari oleh masyarakat Indonesia. Buah yang satu ini memiliki banyak manfaat dan kegunaan bagi manusia. Selain dapat dimanfaatkan sebagai bahan pembuatan makanan dan minuman juga bermanfaat bagi kesehatan tubuh, apel dipercaya dapat mengurangi resiko kanker, dapat digunakan sebagai antioksidan dan dapat menurunkan kadar kolestrol dalam darah. Penelitian yang telah dilakukan sebelumnya melaporkan bahwa kandungan asam malat dalam buah apel juga dapat memutihkan gigi. ${ }^{8}$

Berdasarkan latar belakang di atas penulis tertarik untuk meneliti perbedaan efektivitas penggunaan jus tomat (Lucopersicon esculentum Mill.) dan jus apel (Mallus sylvestris Mill.) sebagai bahan alami pemutih gigi.

\section{BAHAN DAN METODE PENELITIAN}

Jenis penelitian ini ialah eksperimental laboratoris, menggunakan rancangan eksperimental murni (true experimental design) dengan rancangan penelitian pre test-post test only control group design. Penelitian ini dilaksanakan di Laboratorium Farmasi Fakultas MIPA Universitas Sam Ratulangi selama bulan April-Juni 2016.

Sampel penelitian ialah gigi anterior rahang atas dan rahang bawah yang di 
peroleh dari beberapa praktik dokter gigi, Puskesmas, RSUD, dan RSGM yang memenuhi kriteria inklusi yaitu tidak terdapat restorasi, gigi bebas karies, akar terbentuk sempurna dan kriteria eksklusi, gigi yang mengalami fluorosis, gigi sulung, gigi yang mengalami diskolorisasi akar, dan akar gigi perforasi. Besar sampel yang digunakan pada penelitian ini diestimasi menggunakan rumus Federer yaitu 30 sampel yang dibagi atas 3 kelompok, masing-masing terdiri dari 10 sampel.

Semua sampel yang dikumpulkan diberi nomor 1-30 untuk mempermudah melihat perubahan warna sampel tersebut. Bagian akar gigi sampai servikal diolesi cat kuku warna putih bening yang bertujuan untuk menutup akar sehingga larutan kopi tidak berpenetrasi ke dalam tubuli dentin.

Sampel yang telah diberi nomor dan diurutkan direndam dalam larutan kopi selama 12 hari untuk melihat perubahan warna yang terjadi. Setelah 12 hari gigi yang sudah direndam diambil dan dilakukan proses pemotretan. Hasil foto sampel diukur warnanya menggunakan photoshop CS6 portabel dengan menggunakan metode CIEL*a*b*.

Pembuatan jus buah apel dan tomat dengan menggunakan juicer tanpa penambahan air. Hasil jus tomat, apel dan karbamid peroksida $10 \%$ dilakukan pengukuran $\mathrm{pH}$ menggunakan $\mathrm{pH}$ indikator untuk melihat tingkat keasamannya, kemudian jus tomat, apel dan karbamid peroksida $10 \%$ dimasukan ke dalam wadah kaca sebagai tempat untuk melakukan perendaman gigi dengan menggunakan gelas ukur sebanyak $10 \mathrm{ml}$. Sampel nomor 1-10 dimasukan kedalam wadah jus tomat, sampel nomor 11-20 dimasukan kedalam wadah jus apel, dan sampel 21-30 direndam dalam karbamid peroksida 10\%. Masingmasing gigi tersebut direndam selama 1 hari, 3 hari, 5 hari dan dimasukan kedalam inkubator dengan suhu $37^{\circ} \mathrm{C}$. Di setiap pengangkatan perhari dilakukan pengukuran perubahan warna gigi menggunakan metode CIEL*a*b*.

Setelah perendaman sampel dalam jus tomat, jus apel serta karbamid peroksida
$10 \%$ dilakukan pengukuran perubahan warna gigi setelah 1 hari, 3 hari, 5 hari menggunakan metode CIEL*a*b.

\section{HASIL PENELITIAN}

Pada penelitian ini digunakan teknik digital dental photo CIEL*a*b* analysis (metode CIEL*a*b*). Pada metode ini sampel difoto menggunakan kamera DSLR, hasil foto sampel kemudian dianalisis menggunakan software Adobe Photoshop system dengan mode lab color. Metode ini efektif dan efisien untuk melihat nilai perubahan warna email pada gigi.

Uji Shapiro-Wilk terhadap semua data memperlihatkan data terdistribusi normal ( $>0,05)$. Tabel 1 memperlihatkan perbedaan nilai pengamatan warna gigi antara perendaman jus tomat, jus apel dan karbamid peroksida $10 \%$, dan pengamatan sesudah perendaman kopi dengan waktu satu, tiga, lima hari perendaman. Setelah perendaman kopi selama 12 hari, melalui hasil uji beda statistik One Way Anova perbedaan nilai pengamatan warna gigi setelah direndam kopi tidak signifikan $(\mathrm{p}=0,731)$ dan telah dilakukan uji beda lanjut statistik tidak terdapat perbedaan bermakna. Pada hasil pengamatan warna terdapat nilai yang bervariasi. Semakin tinggi nilai pengamatan warna gigi maka gigi semakin putih. Semua gigi yang direndam jus tomat, jus apel dan karbamid peroksida $10 \%$ memperlihatkan perubahan nilai pengamatan warna setiap hari pengukuran dan nilainya semakin tinggi, jadi dapat dikatakan bahwa setiap hari gigi semakin putih.

Setelah satu hari perendaman, jus tomat memiliki nilai warna yang paling besar dibandingkan kelompok sampel yang lainnya, yaitu 55,21, sedangkan yang paling rendah pada karbamid peroksida $10 \%$ 54,14. Pada hasil pengujian beda statistik menggunakan One Way Anova tidak terdapat perbedaan warna yang bermakna antara jus tomat, jus apel dan karbamid peroksida $10 \%(p=0,900)$.

Setelah tiga hari perendaman jus tomat masih memiliki nilai warna yang paling tinggi yaitu 60,16 sedangkan yang paling 
rendah ialah kelompok jus apel yaitu 55,73. Pada hasil uji beda statistik One Way Anova, $p$ value 0,055 , tidak terdapat perbedaan warna yang bermakna pada perendaman hari ke 3 antara gigi yang direndam jus tomat, jus apel dan karbamid peroksida $10 \%$.

Pada pengukuran hari ke lima jus tomat masih memiliki nilai warna yang paling tinggi yaitu 62,86 , jus apel 57,07 , dan karbamid peroksida $10 \%$ 58,41. Hasil uji beda statistik One Way Anova, perendaman hari kelima terdapat perbedaan yang bermakna $(p=0,005)$. Uji beda lanjut nilai pengamatan warna antara perendaman jus tomat, jus apel dan karbamid peroksida $10 \%$ pada waktu pengamatan setelah satu, tiga, lima hari perendaman dapat dilihat pada Tabel 2.

Tabel 1. Perbedaan nilai pengamatan warna gigi setelah satu, tiga, lima hari perendaman menggunakan metode CIEL*a*b*

\begin{tabular}{lcccc}
\hline & \multicolumn{4}{c}{ Nilai pengamatan warna gigi } \\
Jenis larutan & Setelah direndam & Setelah & Setelah & Setelah \\
perendaman & kopi & 1 hari & 3 hari & 5 hari \\
& Mean & Mean & Mean & Mean \\
\hline Tomat & 51,10 & 55,21 & 60,16 & 62,86 \\
Apel & 50,23 & 54,53 & 55,73 & 57,07 \\
Karbamid & 51,96 & 54,14 & 57,08 & 58,41 \\
p-value & 0,731 & 0,900 & 0,055 & $0,005^{*}$ \\
\hline
\end{tabular}

*One Way Anova p<0,05; signifikan

Tabel 2. Hasil uji beda lanjut nilai pengamatan warna gigi setelah satu, tiga, lima hari perendaman

\begin{tabular}{llccc}
\hline $\begin{array}{l}\text { Waktu } \\
\text { perendaman }\end{array}$ & $\begin{array}{l}\text { Larutan } \\
\text { perendaman }(\mathbf{x})\end{array}$ & Perbedaan (y) & $\begin{array}{c}\text { Selisih } \\
\text { rata-rata } \\
(\mathbf{x}-\mathbf{y})\end{array}$ & p-value \\
\hline Setelah 1 hari & Tomat & Apel & 0,68 & 0,737 \\
& & Karbamid & 1,07 & 0,664 \\
& Apel & Karbamid & 0,36 & 0,921 \\
Setelah 3 hari & Tomat & Apel & 4,43 & $0,019^{*}$ \\
& & Karbamid & 3,08 & 0,095 \\
& Apel & Karbamid & $-1,35$ & 0,458 \\
Setelah 5 hari & Tomat & Apel & 5,79 & $0,002^{*}$ \\
& & Karbamid & 4,45 & $0,013^{*}$ \\
& Apel & Karbamid & $-1,34$ & 0,433 \\
\hline
\end{tabular}

*Pos Hoc Test: Least Significant Difference (LSD): $p<0.05:$ significant

Tabel 2 menunjukkan hasil uji beda lanjut nilai pengamatan warna. Pada hari pertama setelah perendaman hasil uji statistik tidak terdapat perubahan warna yang bermakna antara sampel yang direndam jus tomat, jus apel dan karbamid peroksida $10 \%$. Pada hari ketiga terdapat perbandingan bermakna antara jus tomat dan jus apel $(p=0,019)$. Pada hari kelima setelah perendaman antara jus tomat dan jus apel terdapat perbedaan nilai yang bermakna $(p=0,002)$. Pada hari yang kelima, setelah perendaman antara jus tomat dan karbamid peroksida $10 \%$ memiliki nilai perbedaan yang bermakna $(p=0,013)$. Pada hari kelima perendaman antara jus apel dan karbamid peroksida $10 \%$, jus apel yang memiliki nilai 
perubahan warna yang lebih rendah 57,07 dibandingkan karbamid peroksida $10 \%$ yang memiliki nilai 58,41. Walaupun ditemukan perbedaan warna, melalui uji statistik perubahan warna tersebut tidak bermakna.

\section{BAHASAN}

Perubahan warna gigi karena faktor ekstrinsik dapat ditemukan pada permukaan luar gigi yang biasa disebabkan oleh noda/stain tembakau, minuman kopi dan masih banyak lagi. ${ }^{2}$ Bleaching eksternal merupakan cara untuk memutihkan gigi yang berubah warna akibat faktor ekstrinsik dengan proses perbaikan secara kimiawi dan tujuannya ialah mengembalikan fungsi estetika gigi. ${ }^{10}$ Karbamid peroksida merupakan bahan pemutih gigi yang diindikasikan untuk pemutih gigi eksternal dengan konsentrasi 10\%-15\% yang dilakukan dengan teknik home bleaching. ${ }^{5}$

Pemakaian bahan kimia sebagai pemutih gigi tentu akan menyebabkan dampak negatif seperti penurunan kekerasan email, iritasi gingiva dan gigi sensitif. ${ }^{4,10}$ Akibat dampak negatif tersebut maka banyak peneliti yang mulai mencari bahan alami yang berfungsi seperti karbamid peroksida. Bahan alami yang terbukti dapat memutihkan gigi ialah tomat dan apel. ${ }^{7,8}$

Tomat merupakan tanaman yang mudah dijumpai dan memiliki banyak manfaat. Tomat mengandung hidrogen peroksida dan enzim peroksidase yang dapat memutihkan gigi. Hasil penelitian jus tomat lebih efektif memutihkan gigi dibandingkan dengan jus apel dan karbamid peroksida $10 \%$. Hal ini sejalan dengan penelitian Pratiwi $^{7}$ yang melaporkan bahwa perendaman gigi selama tiga hari dalam jus tomat terbukti dapat memutihkan gigi. Penelitian Suwakbur ${ }^{10}$ menunjukkan perendaman gigi selama tiga jam lebih efektif memutihkan gigi dibandingkan dengan karbamid peroksida $10 \%$.

Apel mengandung asam malat yang dapat memutihkan gigi. Hasil penelitian menunjukkan jus apel dapat memutihkan gigi yang direndam selama satu, tiga, lima hari. Hal ini sejalan dengan penelitian Puspasari $^{8}$ yang menunjukkan bahwa gigi yang direndam apel selama 2 minggu efektif memutihkan gigi.

Penelitian ini diawali dengan 30 gigi masing-masing direndam kopi sebanyak 10 $\mathrm{ml}$ selama 12 hari agar terjadi diskolorisasi. Waktu 12 hari dipilih karena berdasarkan uji Wilcoxon sign Rank Test pada penelitian oleh Suwakbur ${ }^{10}$ menunjukkan bahwa terdapat perbedaan nilai pengamatan gigi yang signifikan setelah perendaman kopi $(p<0,05)$. Kopi dipilih sebagai bahan untuk persiapan sampel karena kopi terbukti dapat menyebabkan perubahan warna ekstrinsik pada gigi. Kopi merupakan minuman yang paling sering dikonsumsi sehari-hari oleh masyarakat dan kopi merupakan minuman yang mudah didapatkan. ${ }^{10}$

Pada penelitian ini waktu yang dipilih untuk perendam ialah selama 5 hari dengan pengukuran warna gigi 1 hari, 3 hari, 5 hari. Waktu dipilih karena menurut penelitian Meizarini ${ }^{11}$ bahwa karbamid peroksida $10 \%-22 \%$ efektif memutihkan gigi selama 3-4 minggu dengan pemakaian 2-4 jam perhari setelah dikalkulasikan setara dengan 5 hari dengan pemakaian 24 jam.

Pada penelitian ini digunakan metode CIE L*a*b* sebagai alat ukur. Metode ini dilakukan menggunakan photoshop dengan bantuan kamera. Proses pengambilan gambar pada tempat, posisi dan pencahayaan yang sama pada setiap hari pengukuran. ${ }^{12,13}$

Hasil penelitian mendapatkan perbedaan efektivitas jus tomat dan jus apel. Hal ini terjadi karena kandungan hidrogen peroksida yang terkandung dalam buah tomat. Hidrogen peroksida merupakan senyawa yang efektif untuk memutihkan gigi dengan cara berdifusi melalui email untuk menuju ke tubuli dentin. Bahan ini mampu merusak molekul-molekul zat warna sehingga menyebabkan efek pemutih pada gigi. Tomat juga mengandung enzim peroksidase yang dapat meningkatkan 
kecepatan hidrogen peroksida dalam mereduksi warna. ${ }^{7}$

Menurut hasil penelitian sebelumnya $\mathrm{pH}$ dapat memengaruhi proses pemutih gigi. Semakin rendah $\mathrm{pH}$ dari suatu bahan pemutih gigi maka gigi akan semakin putih. Hasil penelitian ini sejalan dengan teori tersebut. Jus tomat memiliki $\mathrm{pH} 4$ dan karbamid peroksida 10\% memiliki pH 6 . Dari hasil penelitian terbukti bahwa terdapat perbedaan bermakna antara jus tomat dan karbamid peroksida $10 \%$. Tomat memiliki pH yang sama dengan jus apel, namun jus tomat lebih cepat memutihkan gigi. Hal ini disebabkan karena kandungan enzim peroksidase pada jus tomat yang membantu hidrogen peroksida dalam mempercepat proses memutihkan gigi. ${ }^{14,15}$

Konsentrasi molekul dapat membantu proses pemutih gigi. Pada penelitian ini jus tomat dan jus apel diaplikasikan dalam bentuk cair sedangkan karbamid peroksida $10 \%$ dalam bentuk gel sehingga penggunaan jus tomat dan jus apel lebih efektif dibandingkan karbamid peroksida 10\%. Berat molekul juga memengaruhi kecepatan efek pemutih gigi. Berat molekul yang lebih kecil lebih efektif dalam proses pemutih gigi. Berat molekul dari jus tomat dan jus apel lebih kecil dibandingkan karbamid peroksida. Menurut penelitian Miron et al $^{15}$ penggunaan enamel matrix derivate (EMD) yang berfungsi untuk meningkatkan pembentukan sementum, akar, ligamen periodontal dan tulang alveolar, dalam bentuk larutan lebih efektif menembus dan menyerap kebagian dalam dibandingkan dengan EMD dalam bentuk gel. Agen bleaching yang memiliki berat molekul lebih rendah lebih mudah menembus dentin dan enamel dan sebagian untuk menghapus noda. ${ }^{15}$

Pada penelitian sebelumnya, panas dan cahaya dapat memengaruhi proses pemutih gigi. Panas dan cahaya dapat mempercepat proses pemutih gigi dari bahan bleaching kimia. Peningkatan suhu khas yang diinginkan dalam proses dental bleaching yaitu $10^{\circ} \mathrm{C}-40^{\circ} \mathrm{C}$. Pada penelitian ini digunakan inkubator dengan suhu $37^{\circ} \mathrm{C}$; oleh sebab itu juga karbamid peroksida kurang efektif dalam memutihkan gigi. ${ }^{16,17}$

Pada penelitian ini karbamid peroksida $10 \%$ berfungsi sebagai kontrol positif, namun dari hasil penelitian karbamid peroksida $10 \%$ tidak lebih baik memutihkan gigi dibandingkan dengan bahan alami. Limitasi penelitian ini ialah peneliti tidak mengaplikasikan karbamid peroksida sesuai aturan pakainya yang seharusnya menggunakan tray atau sendok cetak khusus dan karbamid peroksida $10 \%$ diganti setiap hari pemakaian. Pada penelitian ini karbamid peroksida $10 \%$ hanya diolesi pada gigi dan diinkubasi. ${ }^{16}$

\section{SIMPULAN}

Dari hasil penelitian dan bahasan dapat disimpulkan terdapat perbedaan bermakna antara efektivitas jus tomat dan jus apel sebagai bahan alami pemutih gigi.

\section{SARAN}

Perlu dilakukan penelitian lebih lanjut tentang tingkat konsentrasi dan keasaman yang efektif dari buah tomat apel dan buah apel manalagi yang dapat diaplikasikan langsung ke dalam mulut pasien.

\section{DAFTAR PUSTAKA}

1. Badan Penelitian dan Pengembangan Kesehatan. Riset kesehatan dasar riskesdas 2013. Jakarta: Kementerian Kesehatan RI, 2013; p.110-11.

2. Grossman LI, Olvet S, Dei Rio CE. Ilmu Endodontik dalam Praktek. Jakarta: EGC, 1995; p. 295.

3. Fauziah C, Fatriyani, Diansari V. Colour change of enamel after application of Averrhoa bilimbi. Journal of Dentistry Indonesia. 2012;19(3):53-6.

4. Riani DR, Oenzil F, Kusuma N. Pengaruh aplikasi bahan pemutih gigi karbamid peroksida $10 \%$ dan hydrogen peroksida 6\% secara home bleaching terhadap kekerasan permukaan email gigi. Jurnal Kesehatan Andalas. 2015;4(2):346-52.

5. Ending S. Penggunaan karbamid peroksida sebagai bahan pemutih gigi. IDJ. 2005; 12 (3):139-45.

6. Margaretha J, Rianti D, Meizarini A. Perubahan warna enamel gigi setelah aplikasi pasta buah stroberi dan gel karbamid peroksida $10 \%$ Effect of 
enamel tooth. Material Dental Journal 2009;1(1):16-20.

7. Pratiwi SA. Pengaruh pemberian jus tomat (Lucopersicon esculentum Mill.) terhadap perubahan warna gigi pada proses pemutihan gigi secara in vitro [Skripsi]. Semarang: Universitas Diponegoro; 2009.

8. Puspasari N, Efendi C, Nugraeni Y. Effect of apple juice on whitening teeth after immersion in coffe solution in vitro. IDJ. 2012;1(2):17-19.

9. Syahland MR, Seriawaty A. Efektivitas penggunaan buah anggur (Vitis vinifera L.) sebagai bahan untuk pemutih gigi (Bleaching) berdasarkan perbedaan konsentrasi. IDJ. 2013;2(1):50-6

10. Sawakbur S. Perbandingan efektivitas pengguunaan buah stroberi (Fragaria xannanassea) dengan buah tomat (Lucopersicon esculentum Mill.) sebagai bahan alami pemutih gigi secara in vitro [Skripsi]. Makasar: Universitas Hasanuddin; 2105.

11. Meizarini A, Rianti, D. Bahan pemutih gigi dengan sertifikat ADA/ISO. Dental
Journal. 2005;38(2):73-5.

12. Suratman. Perbedaan diskolorisasi restorasi resin komposit pada perendaman larutan teh hijau dan teh hitam [Skripsi]. Makassar: Universitas Hasanuddin; 2014.

13. Indriyani. Model pengeringan lapisan tipis temu putih [skripsi]. Makassar: Universitas Hasanuddin; 2012.

14. Andhani R, Widodo, Sukmana BL, Suhartoni E. Effect $\mathrm{pH}$ on demineralization dental erosion. IJCA. 2015;6(2):138-41.

15. Richard BT, Sedarous M, Hiltz GS. The $\mathrm{pH}$ of tooth whitening product. J Can Assoc. 2000;66:491-6.

16. Adang RAF, Suprastiwi E, Usman M. Pemutihan gigi teknik Home Beaching dengan menggunakan karbamid peroksida. IJD. 2006; Edisi khusus XIV.

17. Gutknecht N, Franzen R, Meister J, Lukac M, Pirnat S,Zabkar J, et al. A Novel Er: YAG Laser-Assisted Tooth Whitening Method. J LAHA. 2011; 11(1):1-10. 